Provided for non-commercial research and education use. Not for reproduction, distribution or commercial use.

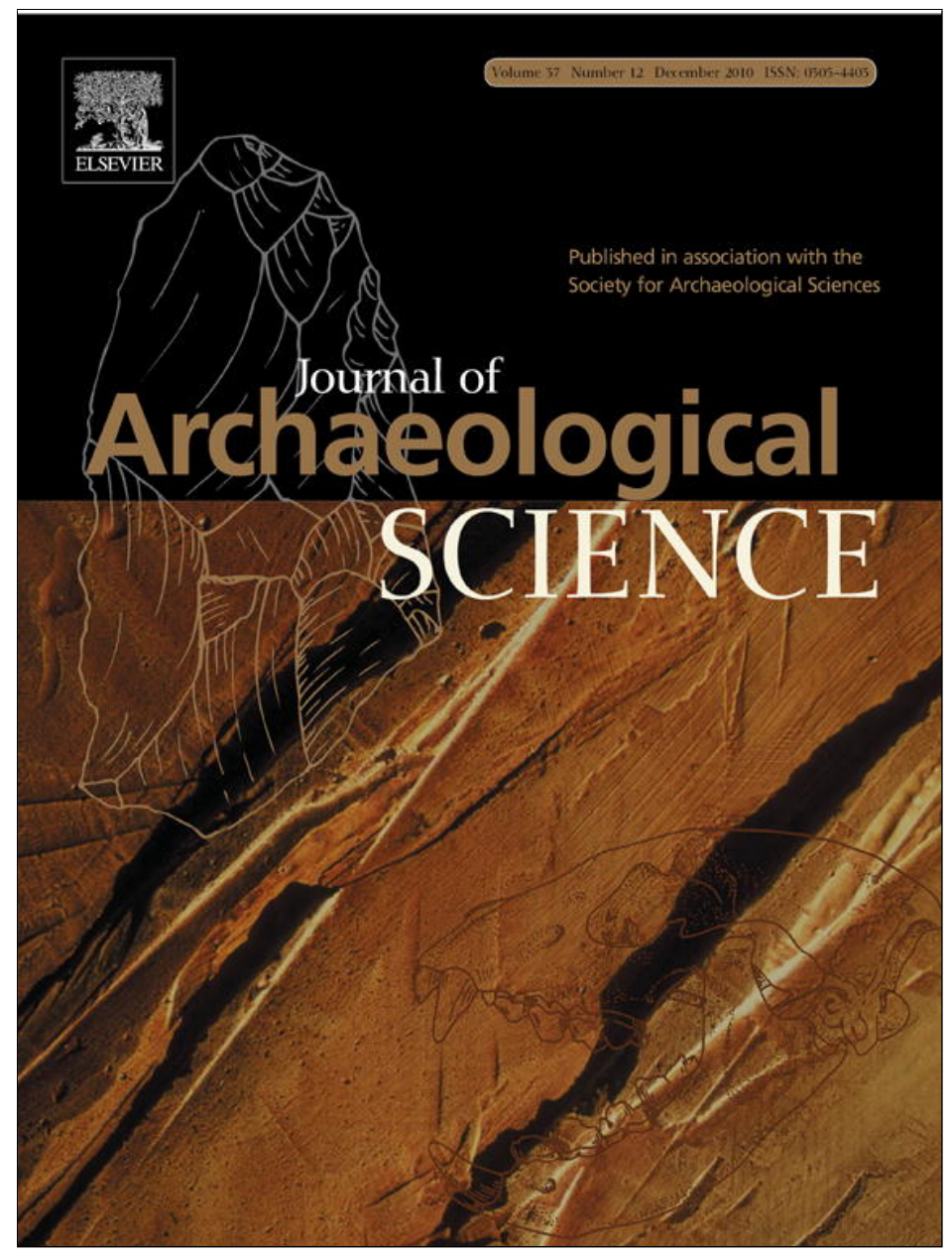

This article appeared in a journal published by Elsevier. The attached copy is furnished to the author for internal non-commercial research and education use, including for instruction at the authors institution and sharing with colleagues.

Other uses, including reproduction and distribution, or selling or licensing copies, or posting to personal, institutional or third party websites are prohibited.

In most cases authors are permitted to post their version of the article (e.g. in Word or Tex form) to their personal website or institutional repository. Authors requiring further information regarding Elsevier's archiving and manuscript policies are encouraged to visit:

http://www.elsevier.com/copyright 


\title{
Palaeolithic engravings and sedimentary environments in the Côa River Valley (Portugal): implications for the detection, interpretation and dating of open-air rock art
}

\author{
Thierry Aubry $^{\mathrm{a}, *}$, Luca Antonio Dimuccio ${ }^{\mathrm{b}, \mathrm{c}}$, M. Mercè Bergadà ${ }^{\mathrm{d}}$, Jorge Davide Sampaio ${ }^{\mathrm{a}}$, Farid Sellami ${ }^{\mathrm{e}}$ \\ a IGESPAR-IP, Instituto de Gestão do Património Arquitectónico e Arqueológico, Parque Arqueológico do Vale do Côa, Avenida Gago Coutinho e Sacadura Cabral, 19-A, \\ 5150-610 Vila Nova de Foz Côa, Portugal \\ ${ }^{\mathrm{b}}$ Centro de Estudos de Geografia e Ordenamento do Território (CEGOT), Faculdade de Letras, Universidade de Coimbra, Praça da Porta Férrea, $3004-530$ Coimbra, Portugal \\ ${ }^{\mathrm{c}}$ Departamento de Ciências da Terra, Faculdade de Ciências e Tecnologia, Universidade de Coimbra, Largo Marquês de Pombal, $3000-272$ Coimbra, Portugal \\ ${ }^{\mathrm{d}}$ SERP, Departament de Prehistòria, Història Antiga i Arqueologia, Facultat de Geografia i Història. UBC/Montalegre 6-808001 Barcelona, Spain \\ e INRAP, Direction interrégionale Grand-Sud-Ouest. BP 161, 210 cours Victor-Hugo, 33130 Bègles, France
}

\section{A R T I C L E I N F O}

\section{Article history:}

Received 20 March 2010

Received in revised form

23 July 2010

Accepted 29 July 2010

\section{Keywords:}

Côa River valley

Palaeolithic rock art

Open-air engravings

Fluvial sedimentary environment

Rock art preservation

\begin{abstract}
A B S T R A C T
The pre-Magdalenian phase of the Côa River Valley open-air rock art is mostly distributed at the boundary between the rocky valley slopes and the floodplain that correspond to the most favourable geomorphological setting for the preservation of pecked and deeply superposed engravings of the most famous artistic phase of the area. The natural vertical panels of the engraved art located at this geomorphological interface have suffered weathering during two cold events of the Lateglacial. They were buried by several colluvial and alluvial deposits. The reconstruction of the sedimentary and archaeological context of the CôaRiver Valley engraving permits a better assessment of the preservation processes and interpretation of Palaeolithic open-air rock art.
\end{abstract}

(c) 2010 Elsevier Ltd. All rights reserved.

\section{Introduction}

One century after the discovery of the first Palaeolithic representations in caves, the interpretation of the Mazouco open-air engravings as contemporaneous implied that rock art of this period could be preserved out of caves or rock-shelters (Jorge et al.,1981). At the end of the twentieth century, other open-air rock art panels exposed to weathering in Iberia and southern France were also attributed to the Palaeolithic period (Fig. 1A). These petroglyphs were found in the Spanish sector of the Douro drainage basin, at the Siega Verde (Balbín Behrmann et al., 1991) and Domingo Gárcia sites (Rippol and Municio, 1992) and in the Spanish Guadiana watersheds at Molino Manzanez (Collado, 2009). In Portugal, these engravings were found in the lower valley of the Côa and Sabor rivers (Baptista,

\footnotetext{
* Corresponding author. Tel.: +351 239443992. Urbanização São Bento, Lote 65, Casais do Campo, 3045-120 Coimbra, Portugal.

E-mail addresses: thaubry@sapo.pt (T. Aubry), luca@ci.uc.pt (L.A. Dimuccio) bergada@ub.edu (M.M. Bergadà), jsampaio.pavc@igespar.pt (J.D. Sampaio), Farid. sellami@inrap.fr (F. Sellami).
}

1999, 2001; Baptista and Varela Gomes, 1995; Zilhão, 1997), along the Ocreza (Baptista, 2001) and the Zêzere rivers (Baptista, 2004) and along the right margin tributaries of the TagusRiver. The site of Fornols-Haut (Bahn, 1985; Sacchi et al., 1988) remained the only open-air rock art site known north of the Pyrenees (Fig. 1A).

Despite a clear increase in the rate of its detection in recent years, thirty years after its first discovery open-air rock art represents only a small percentage of all the rock art representations assigned to the Palaeolithic. Some researchers consider this proportion to reflect the Palaeolithic preference for cave and rock-shelter settings. Others argue that it is not representative and that the open-air images were a common and permanent component of the Palaeolithic monumental art (Sacchi, 2002; Bahn, 1995), but were mostly destroyed because of their direct exposure to weathering (Zilhão, 1997).

The aim of this paper is to establish the relationship between the oldest phase of the Palaeolithic rock art cycles recognised in the CôaRiver Valley and the associated Quaternary sediments in light of the floodplain deposit's accumulation and its interrelation with palaeoclimatic changes. From these data, we try to explain the process and mechanisms that have permitted the conservation of these engravings, despite episodes of weathering that have affected 


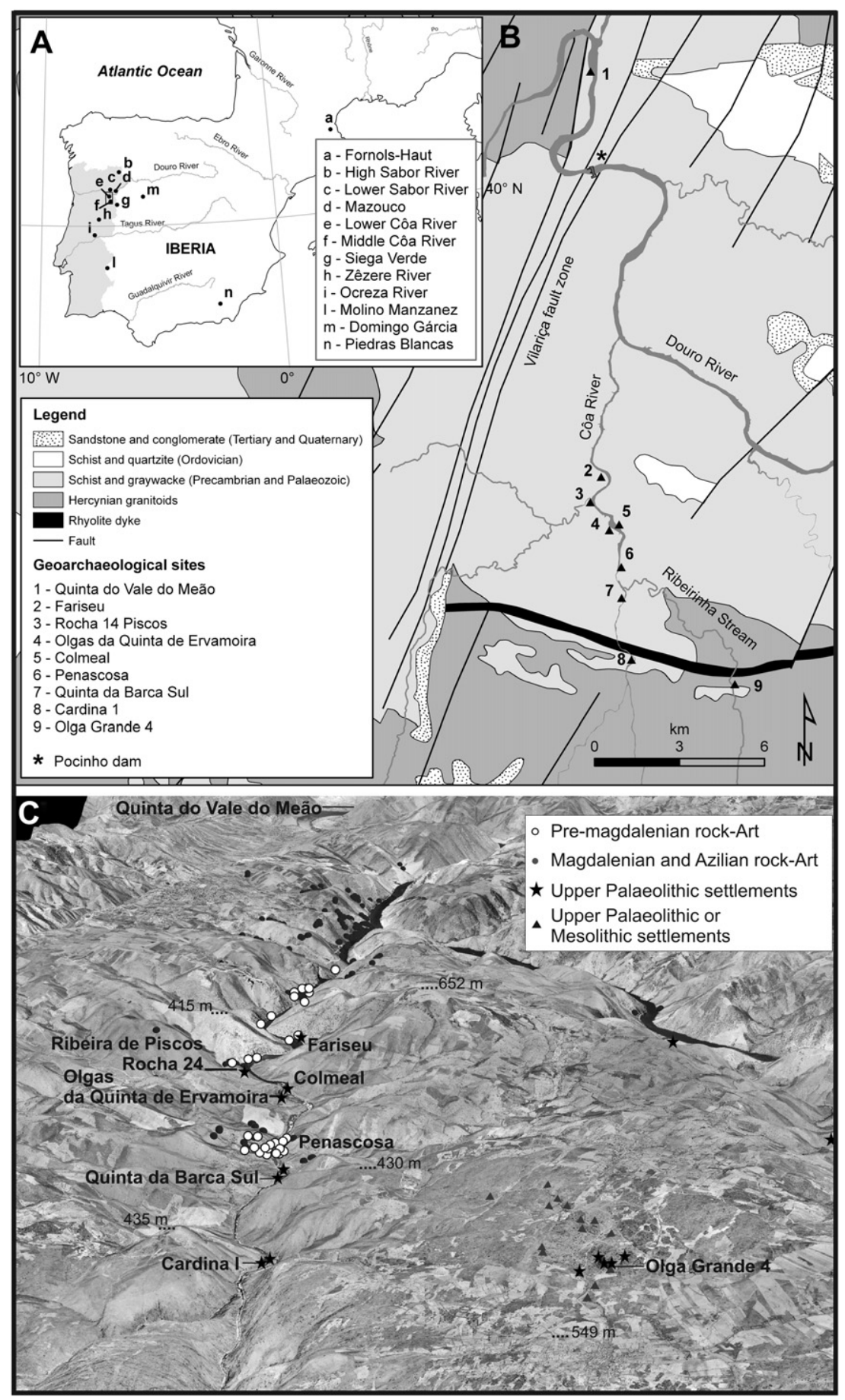

Fig. 1. Open-air rock art of Iberia and southern France (a), geological setting of the low Côa River Valley (b), distribution of the Palaeolithic rock art phases and contemporary sites of habitat of the low valley of the CôaRiver (c).

the rocky outcrops used as support. Furthermore, we attempt to define their visibility (or lack of visibility) during time. The results allow a new approach to the issue of open-air rock art and its interpretation in the context of the oldest European Palaeolithic art testimonies.

\section{Regional setting and Palaeolithic engraving location}

The Côa River is a Portuguese left-bank tributary of the Douro River, one of the major watercourses that cross the NW Iberian mountains from east to west. The $120-\mathrm{km}$ long river basin, $\mathrm{N}-\mathrm{S}$ aligned due to tectonic control, comprises two different geological sectors (Fig. 1B). The upstream sector, down to the last $17 \mathrm{~km}$ before the confluence with the Douro River, is through Hercynian granitoids. The downstream sector grades to a meandering pattern cut in Precambrian, Palaeozoic and Ordovician metamorphic rocks (mostly schist).

Currently, the hydrologic regime of the river discharge is directly imposed by rainfall and controlled by direct runoff induced by the sharp gradient and the scarce vegetation cover. However, the Last 
Glacial Maximum (LGM) temperature reconstruction model for the coldest month of the year implies that, at this time, precipitation accumulated in the form of snow cover, and the annual discharge was more evenly distributed due to the underground flow and the spring snowmelt (Aubry et al., 2002).

The Palaeolithic engraving art of the CôaRiver Valley was discovered at the end of the 1990s, during the construction of a dam project later discarded. The engravings, made by incision, scraping and pecking, are preserved on naturally vertical diaclases on the schist and granitoids Hercynian basement. The stylistically Palaeolithic engravings are scattered over the $22 \mathrm{~km}$ of the Côa and Douro rivers and some tributaries near their confluence (Figs. 1C and 3). However, the survey of the entire floodplain margin is not possible because the lower portion (below $125 \mathrm{~m}$ of elevation) of the downstream $7 \mathrm{~km}$ of the Côa River Valley (from the Olgas da Ervamoira site to the confluence with the Douro) is inundated by the tail of the reservoir of the Pocinho dam, built a few kilometres downstream from the confluence with the Douro (Fig. 1B).
The vertical joints were progressively open and exposed by traction and tilting due to stress relief during the incision of the CôaRiver (Fernandes, 2009). The incision process is evidenced by terraces deposited on the Côa margins in the Late Pleistocene (Aubry et al., 2002).

\subsection{CôaRiver valley Palaeolithic rock art phases}

The engraved diaclases are covered by siliceous and metallic films subject to a constant process of re-deposition (Pope, 2000). Small fragments of organic material contained within the tracing, in and under these films, were subject to direct dating by the ${ }^{14} \mathrm{C}$ AMS method, revealing Holocene origins (Watchman, 1995, 1996). However, the results obtained by the same method on the rock art tracing and the adjacent natural surfaces presented by Dorn (1997) confirmed the hypothesis advanced by Zilhão (1995) and proved that the metallic and siliceous films of the engraved surface do not constitute a closed and stable system.
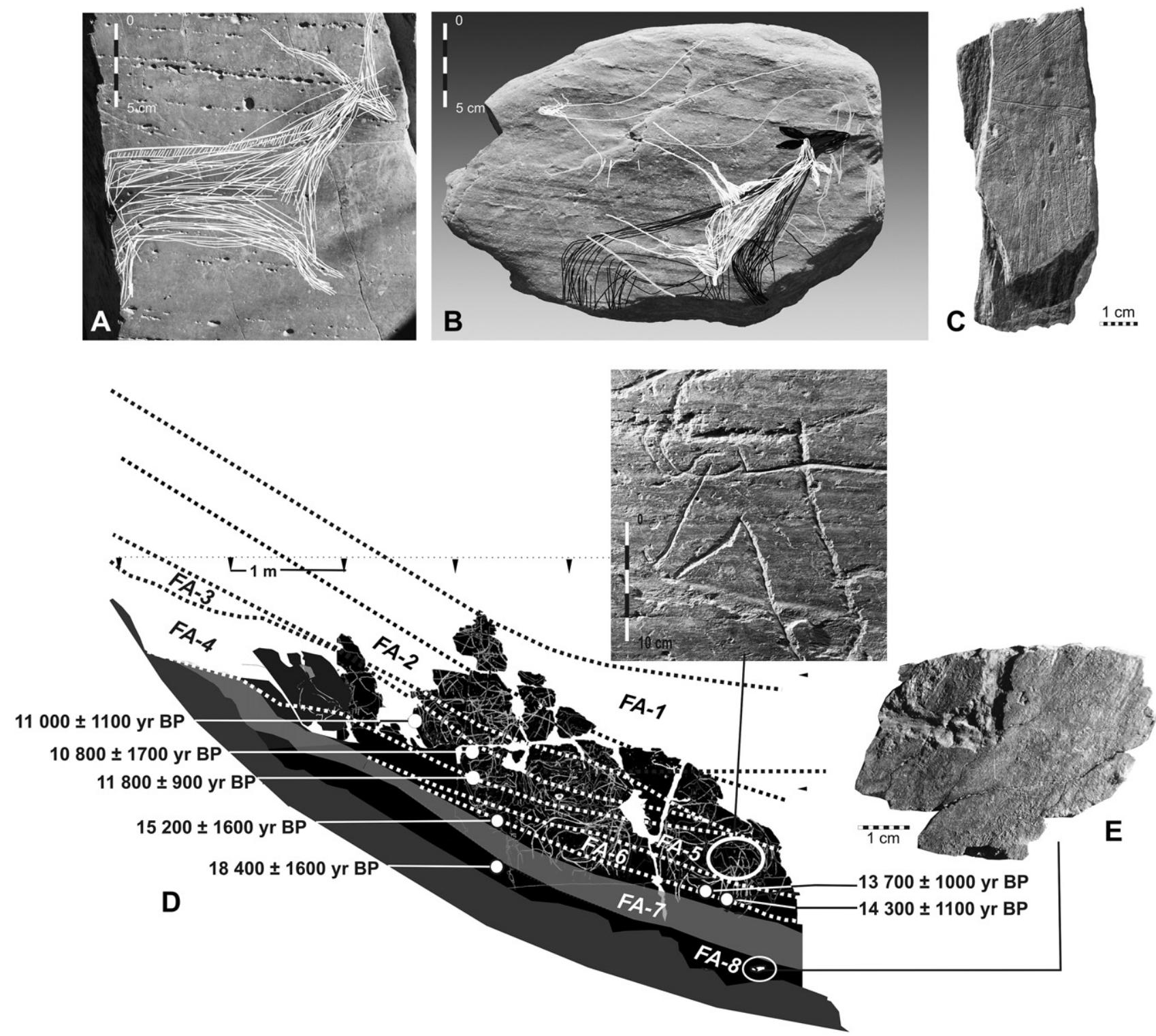

Fig. 2. Detail of the Vale de José Esteves Rock $16(\mathrm{a}-\mathrm{b})$, portable art on schist slab from Fariseu. Stratigraphic unit FA-4 dated by luminescence to ca. $11000-12000$ BP and by ${ }^{14} \mathrm{C}$ to $10000-12000 \mathrm{cal}$ yr BP (c), and stratigraphic unit FA-7 dated by luminescence between 18 400-15 $000 \mathrm{BP}$ (d), Fariseu, scheme of the stratigraphical units conserved in front of Rock 1 representative of the older Palaeolithic rock art phase of the Côa River Valley, and fragment of the engraved panel recovered in the unit FA- 8 dated by OSL ca. 18400 yr BP (e). 


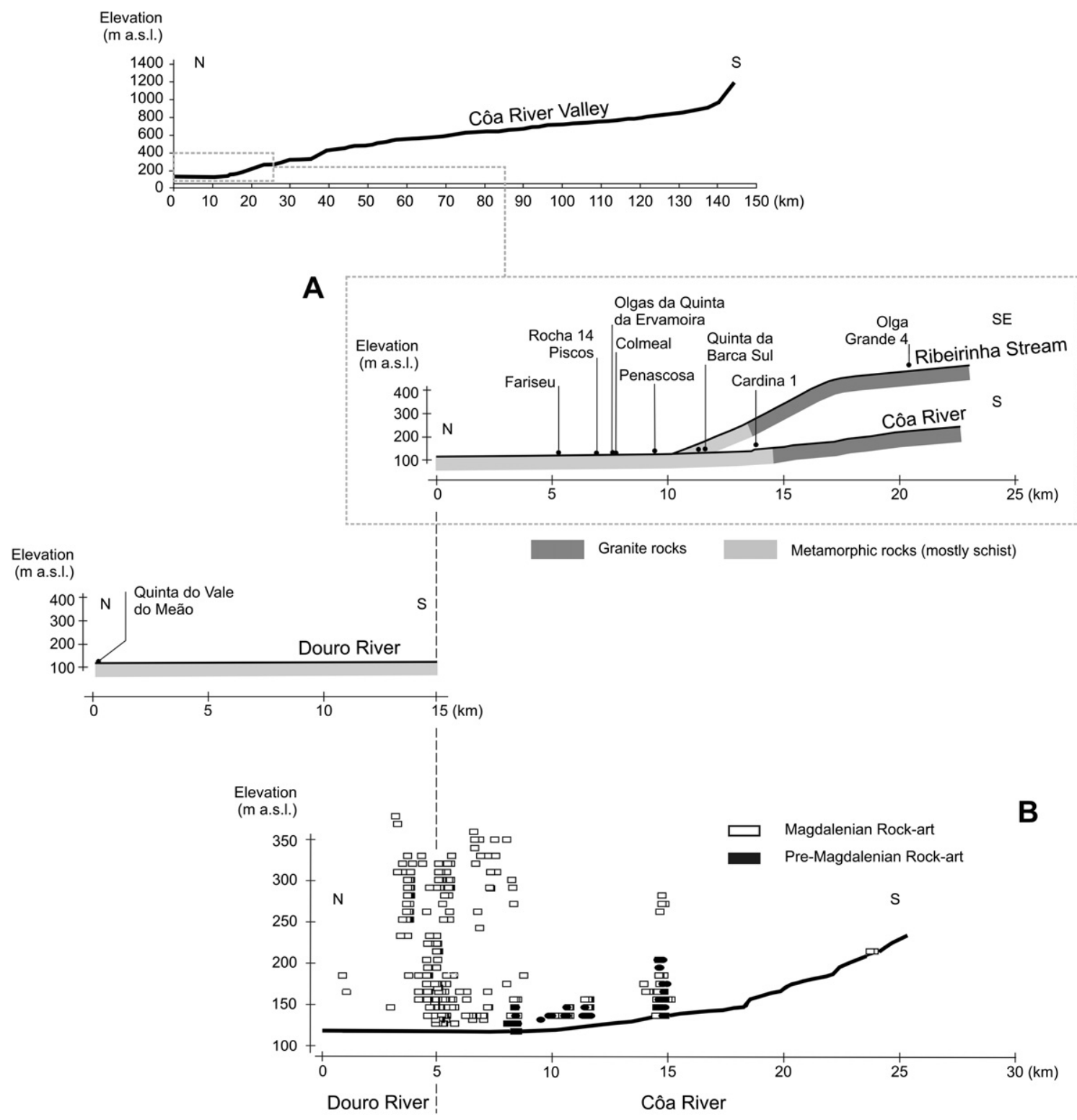

Fig. 3. Position of the sites according to the longitudinal profile of the Côa and Douro Rivers (a), distribution of the rock art of two Upper Palaeolithic artistic phases (L. Luís) (b).

Confirmation that the dates obtained by the ${ }^{14} \mathrm{C}$ method provided, at best, only minimum ages, was obtained in December 1999. At that time, maintenance work along the Douro River enabled a survey of a section of the CôaRiver Valley usually covered by the Pocinho reservoir. A test at the Fariseu site (Fig. 1B and C), at a meander of the left bank of the river on the schist portion of the valley, revealed a sedimentary sequence preserved at the contact with an engraved panel, Rock 1 of Fariseu (inventory number of the rock art panels of the site of the Côa Valley Archaeological Park). A combination of the stratigraphic sequence, archaeological lithic assemblages (Aubry and Baptista, 2000; Aubry et al., 2002) and dating by Thermoluminescence (TL) and Optically Stimulated Luminescence (OSL) (Mercier et al., 2006) has confirmed the stylistic and archaeological arguments advanced by Zilhão (1995) and contributes to the establishment of a relative and absolute chronology of the Côa Valley rock art. The archaeological data reveal two main periods of artistic production in the valley during the Upper Palaeolithic. The more recent period, dated by TL between ca. $10800 \mathrm{BP}$ and $11800 \mathrm{BP}$, is represented by rock art and portable art (Fig. 2A and B). The older period corresponds to the famous pecked and deeply incised representations of the Côa
Valley World Heritage (Fig. 2D; Baptista, 1999; Baptista et al., 2008, 2009). These engravings were done before ca. $18400 \pm 1600 \mathrm{BP}$, the age of the FA- 8 geoarchaeological field unit of the Fariseu site dated by OSL, where an engraved fragment of the rock panel was discovery in 2007. Although it does not connect directly with the incomplete figures on Rock 1, the position of the engravings and their similarities with the engravings on Rock 1 allow us to propose that this panel was engraved before this layer formed (Fig. 2E; Aubry and Sampaio, 2008; Mercier et al., 2006). This evidence provides a minimum age for the engravings of this artistic phase that would be significantly older.

A prior human occupation of the site is suggested by the age of $19020 \pm 80{ }^{14} \mathrm{C}$ yr BP (22 581-23 174 cal yr BP) obtained from a charcoal fragment found at the bottom of the sequence excavated in the central part of the Fariseu site. Nevertheless, the direct relationship between this date and the older graphic phase, represented by the engraving of Rock 1 , cannot be definitively established.

The survey carried out since 1995 in the CôaValley Archaeological Park has revealed new engraved panels of different chronology. From 2004 to 2006, the total number of engraved panels increased from 330 to 664 (Baptista and Reis, 2009). Of these, 330 
panels could be stylistically attributed to the Palaeolithic (Fig. 1C). However, a stylistic comparison with the representations of portable art on schist slabs, found in the Fariseu site geoarchaeological field units dated by TL, OSL and ${ }^{14} \mathrm{C}$ AMS, shows that the majority Palaeolithic engravings discovered during the 21st century were realized by the fine incision technique during the Younger Dryas (Fig. 2A; Aubry, 2009; Aubry and Garcia Diez, 2001; Aubry and Sampaio, 2008). The panels ascribed to this late Palaeolithic artistic phase are distributed over the whole slope of the lower Côa hydrographic basin and show a stronger density towards the junction with the Douro River Valley (Figs. 1 and 3). A panel of cervidae and capridae carved by the incision technique was found in 2008 at the top of a schist plateau near the Vila Nova de Foz Côa city (Baptista and Reis, 2009). In contrast, despite the systematic survey, the pecked and deeply incised engravings of the older stylistic phase similar to the Fariseu Rock 1 (Baptista et al., 2008, 2009; Baptista and Santos, 2010) remained concentrated in the lowest portion of the valley slopes (below $200 \mathrm{~m}$ a.s.l.) and along $8 \mathrm{~km}$ of metamorphic rocks (Fig. 3). This geographical, topographical and lithological distribution enabled us to propose a differential preservation according to the effect of meteoric agents varying with elevation and temperature, petrography of the bedrock and preengraving tectonic deformations (Aubry et al., 2002; Zilhão, 2003).

At the Fariseu site, in the FA-7 geoarchaeological field unit of the stratigraphical sequence at the Rock 1 interface (over the FA- 8 unit dated by TL to $18400 \pm 1600 \mathrm{BP}$ and under the FA- 6 unit dated $15200 \pm 1600$ BP; Fig. 2), a fragment of engraved portable schist slab was discovered. This fragment contained a representation of an incomplete animal with multiple incisions and tracings (Fig. 2C). This discovery not only proves the existence of an intermediary artistic phase but also documents the use of this artistic convention during that phase.

\section{Material and methods}

The information presented here is derived from stratigraphic archaeological remains and chronological data collected at the CôaRiver Valley sites, using the standard geoarchaeological fieldwork approach: a geomorphological study of the site surroundings, a field description of the site deposits and stratigraphic correlation, and finally the selection of sampling location for micromorphology and dating. Fieldwork at the sites included the systematic description of exposed cross-sections and profiles to reconstruct stratigraphic successions, their vertical and lateral variations and archaeological contents (Table 1 and Fig. 4). The description was made using a comprehensive form addressing the sedimentary, pedogenic and anthropogenic characteristics of the deposits (e.g., Keeley and Machail, 1981; FAO-Isric, 1990; Brown, 1997) to recognize the site formation processes. Informal geoarchaeological field units (GFU) were identified on the basis of lithostratigraphic, pedological or archaeological criteria and used as field categories.

Data provided by the macroscopic approach of the GFU are supported by the micromorphological study of samples collected along the Fariseu Rock 1 sequence (Sellami, 2009a), at Olga Grande 4 and 14 sites located on the granitic plateau (Sellami, 2009b) and, on schist, at Cardina I site (Bergadà, 2009; Bergadà et al., 2009).

The correlation between GFU of the several sites rests upon the reconstruction of their genetic processes and the environment of deposition, based on particle size distribution, fabric and structure, archaeological contents and chronometric dating. The chronological data (Table 2) were obtained by Accelerator Mass Spectrometry (AMS) and conventional ${ }^{14} \mathrm{C}$ analysis (Sacavém Laboratory - Sac), as well as OSL and TL When appropriate, original ${ }^{14} \mathrm{C}$ conventional data and AMS data were converted into calendar age (cal yr BP) using CalPal calibration from Weninger and Jöris (2004) with the
Calcurve CalPal_2007_HULU (www.calpal-online.de). All the errors are 1-sigma.

In parallel with the interpretation of direct field observations on the Côa River Valley, stratigraphical, sedimentological and chronometric data are provided by a mechanically-dug trial trench (orientated perpendicularly to the Vilariça fault zone and carried out in the left margin of the Douro River, in the vineyard of Quinta do Vale do Meão) (Fig. 1B) to date and assess fault displacements (Rockwell et al., 2009).

\section{Stratigraphic and chronological data of the CôaRiver valley sites}

\subsection{Olga Grande 4}

Locus 4 of the Olga Grande site (locally called Pedras Altas) is one of a cluster of sites located along the right bank of the Ribeirinha Rivulet, a tributary of the Côa River draining the granitic plateau corresponding to the Pliocene erosional surface of the Iberian Meseta (Aubry et al., 2002; Aubry, 2009; Fig. 1B and C). The sequence observed at the Olga Grande 4 site during archaeological work between 1999 and 2002 is composed of four GFU, corresponding to granitic sands accumulated on ledges and hollows circumscribed by rock outcrops (Sellami, 2009b). Bronze Age and Neolithic ceramics and lithic remains are conserved in the disturbed uppermost unit. The remaining undisturbed sequence contain several chronological and cultural stages of the Middle and Upper Palaeolithic (Middle Gravettian, Upper Solutrean and Upper Magdalenian), established by the typology of lithic assemblages and absolute dating methods (Tables 1 and 2).

\subsection{Cardina 1}

The sequence observed during archaeological work between 1995 and 2001 is conserved on a rock terrace, $20 \mathrm{~m}$ above the CôaRiver bed level, which corresponds to a deviation of the watercourse caused by a rhyolite dyke (Fig. 1B). The bottom of the sedimentary sequence is not known. Four GFU were defined during the archaeological work, accumulated by surface runoff (Bergadà, 2009; Bergada et al., 2009). These range from the late Pleistocene period, including Upper Palaeolithic (recent Gravettian, Solutrean, Magdalenian and final Magdalenian, respectively, at the bottom, middle and top of the - OG4-3 GFU), established by the typology of lithic assemblages and absolute dating methods, as well as the modern and Neolithic to Bronze Age ceramic fragments and flint bladelets recovered in the two uppermost GFU (Tables 1 and 2).

\subsection{Quinta da Barca Sul}

The site corresponds to a topographic break on a sharp schistose slope $10 \mathrm{~m}$ above the riverbed, located on the left margin of the CôaRiver (Fig. 1B and C). The sedimentary sequence observed during archaeological works between 1998 and 2001 (Aubry, 2009) is constituted by colluvial (QBS- 1 to $3 \mathrm{~b}$ units) and alluvial (QBS- 4 unit) deposits conserved on the top of a schist rock terrace, constituting a topographic break of slope favourable to the accumulation of fine sediments and weathering debris (Fig. 4). The QBS$3 \mathrm{~b}$ unit contains flint and fine-grained siliceous rock curved backed points, characteristic of the final Magdalenian phase in Portugal (contemporaneous with the Azilian phase of the Pyrenean and southern France regions); it was dated by TL between ca. $11600 \mathrm{BP}$ and $12700 \mathrm{BP}$ (Table 2). A few lithic remains that could technologically be ascribed to an undefined Upper Palaeolithic phase were recovered in the discontinuous alluvial QBS-4 unit (Aubry, 2009). 
Table 1

Geographical, geomorphological and archaeological contexts of the sites discussed in the text.

\begin{tabular}{|c|c|c|c|c|c|c|}
\hline Archaeological Site & Longitude & Latitude & $\begin{array}{l}\text { Altitude } \\
(\mathrm{m})\end{array}$ & Geomorphological context & Cultural context & References \\
\hline Olga Grande 4 & $40^{\circ} 58^{\prime} 10,44^{\prime \prime} \mathrm{N}$ & $7^{\circ} 03^{\prime} 23,43^{\prime \prime} \mathrm{W}$ & 510 & $\begin{array}{l}\text { Topographic break on granitic bedrock between } \\
\text { top slope and floodplain (Côa River) }\end{array}$ & N/B, UP, MP & Aubry (2009) \\
\hline Cardina 1 & $40^{\circ} 58^{\prime} 46,11^{\prime \prime} \mathrm{N}$ & $7^{\circ} 06^{\prime} 01,89^{\prime \prime} \mathrm{W}$ & 165 & Fluvial rock terrace on schist bedrock (Côa River) & M, B, C, UP & $\begin{array}{l}\text { Zilhão (1997); } \\
\text { Aubry et al. (2002); } \\
\text { Aubry (2009); } \\
\text { Valladas et al. (2001) }\end{array}$ \\
\hline Quinta da Barca Sul & $40^{\circ} 59^{\prime} 54,01^{\prime \prime} \mathrm{N}$ & $7^{\circ} 06^{\prime} 14,09^{\prime \prime} \mathrm{W}$ & 143 & Fluvial rock terrace on schist bedrock (Cõa River) & $\begin{array}{l}\text { N/C?, B?, } \\
\text { ME, UP }\end{array}$ & $\begin{array}{l}\text { Zilhão (1997); } \\
\text { Aubry (2009); } \\
\text { Valladas et al. (2001) }\end{array}$ \\
\hline Penascosa & $41^{\circ} 06^{\prime} 30,33^{\prime \prime} \mathrm{N}$ & $7^{\circ} 06^{\prime \prime} 17,08^{\prime \prime} \mathrm{W}$ & 140 & $\begin{array}{l}\text { Fluvial rock terrace at the interface between schist } \\
\text { bedrock slope and floodplain (Côa River) }\end{array}$ & $\mathrm{M}, \mathrm{N} / \mathrm{C}$ & $\begin{array}{l}\text { Zilhão (1997); } \\
\text { Aubry (2009) }\end{array}$ \\
\hline Colmeal & $41^{\circ} 01^{\prime} 17,03^{\prime \prime} \mathrm{N}$ & $7^{\circ} 06^{\prime} 18,39^{\prime \prime} \mathrm{W}$ & 130 & $\begin{array}{l}\text { Fluvial rock terrace at the interface between schist } \\
\text { bedrock slope and floodplain (Côa River) }\end{array}$ & M, UP? & Aubry (2009) \\
\hline $\begin{array}{l}\text { Olgas da Quinta } \\
\text { de Ervamoira }\end{array}$ & $41^{\circ} 01^{\prime} 16,43^{\prime \prime} \mathrm{N}$ & $7^{\circ} 06^{\prime} 33,61^{\prime \prime} \mathrm{W}$ & 135 & $\begin{array}{l}\text { Fluvial rock terrace at the interface between } \\
\text { schist bedrock slope and floodplain (Côa River) }\end{array}$ & N/C, B?, UP? & \\
\hline Rocha 14 Piscos & $41^{\circ} 01^{\prime} 48,17^{\prime \prime} \mathrm{N}$ & $7^{\circ} 06^{\prime} 58,91^{\prime \prime} \mathrm{W}$ & 130 & $\begin{array}{l}\text { Small topographic break on schist bedrock } \\
\text { slope (Côa River) }\end{array}$ & UP?, RA & Aubry (2009) \\
\hline Fariseu & $41^{\circ} 02^{\prime} 16,64^{\prime \prime} \mathrm{N}$ & $7^{\circ} 06^{\prime} 36,53^{\prime \prime} \mathrm{W}$ & 125 & $\begin{array}{l}\text { Fluvial rock terrace at the interface between schist } \\
\text { bedrock slope and floodplain (Côa River) }\end{array}$ & $\begin{array}{l}\text { M, N/C?, B?, } \\
\text { UP, RA }\end{array}$ & $\begin{array}{l}\text { Aubry et al. (2002); } \\
\text { Aubry (2009); } \\
\text { Mercier et al. (2006); } \\
\text { Aubry and Sampaio (2008) }\end{array}$ \\
\hline Quinta do Vale do Meão & $41^{\circ} 09^{\prime} 59,35^{\prime \prime} \mathrm{N}$ & $7^{\circ} 06^{\prime} 54,70^{\prime \prime} \mathrm{W}$ & 110 & $\begin{array}{l}\text { Fluvial rock terrace at the interface between schist } \\
\text { bedrock slope and floodplain (Douro River) }\end{array}$ & M & Rockwell et al. (2009) \\
\hline
\end{tabular}

$\overline{\mathrm{M}}=$ Modern/Medieval; $\mathrm{B}=$ Bronze Age; $\mathrm{N}=$ Neolithic; $\mathrm{C}=$ Chalcolithic; ME = Mesolithic; UP = Upper Palaeolithic; MP = Middle Palaeolithic; RA = Palaeolithic Rock-Art.

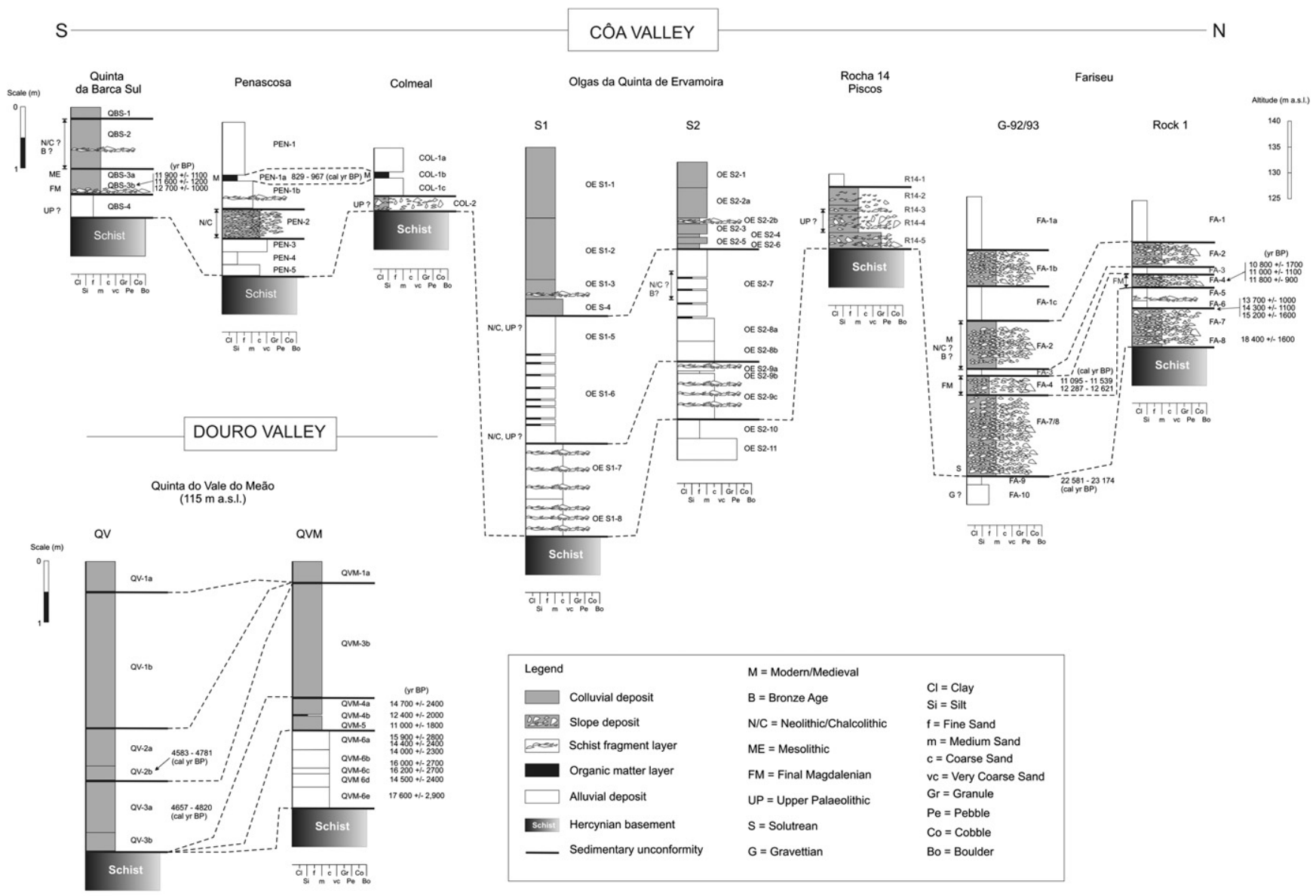

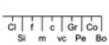

Fig. 4. Correlative framework and description of the floodplain alluvial units (white) and colluvial and slope deposits (grey) of the Côa River Valley and at Quinta do Vale do Meão, in the Douro River Valley. 


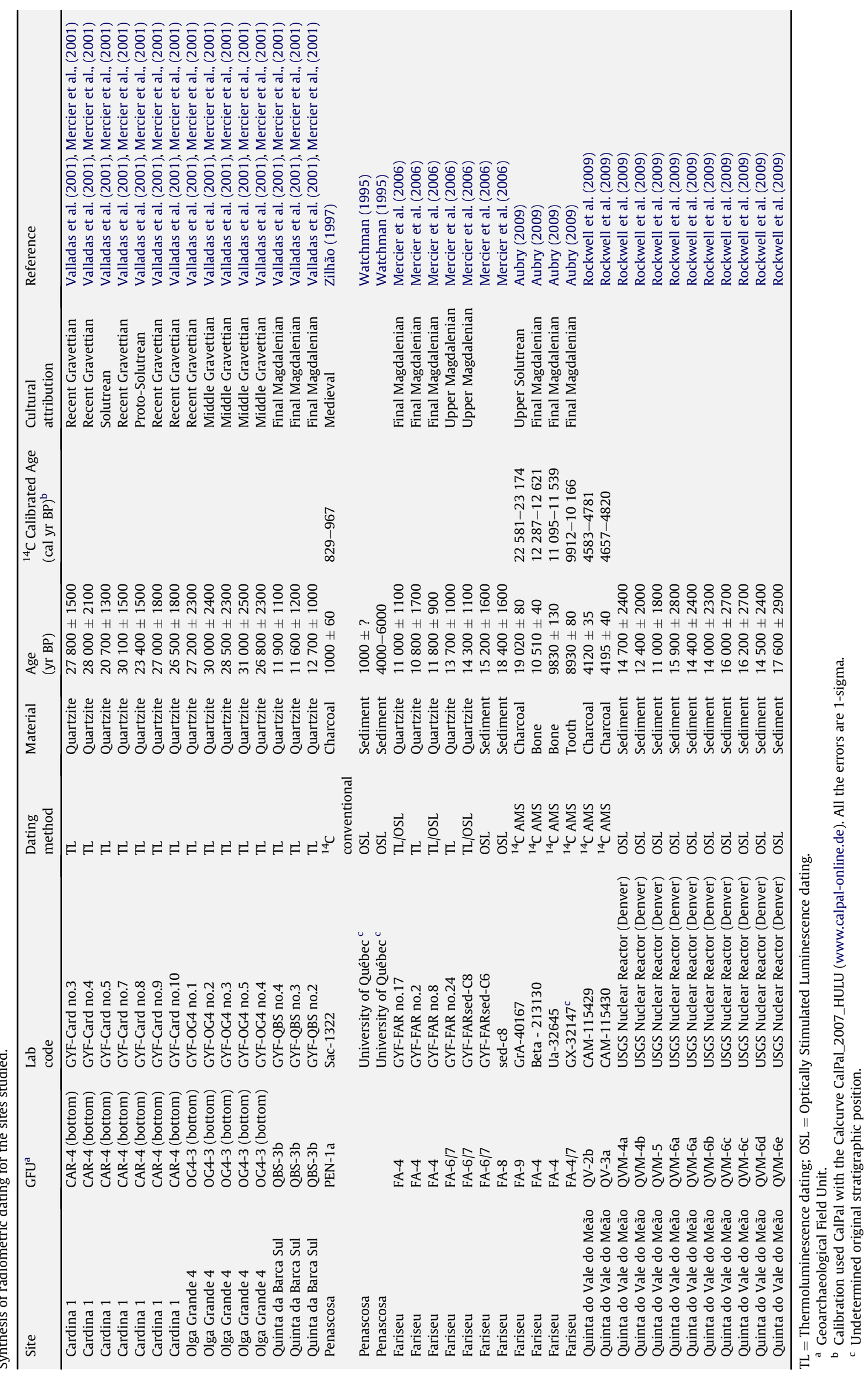




\subsection{Penascosa}

The section studied is located on the right bank of the CôaRiver, downstream from the Penascosa engraving site (Fig. 1B and C). The stratigraphic sequence of the floodplain at its contact with the schistose slope was obtained by a machine-dug trench perpendicular to the river (Zilhão, 1997). An archaeological test was completed near the slope in the trench. The sequence is composed of four alluvial GFU (PEN-1, 3, 4 and 5) intercalated with a slope deposit (PEN-2 unit; Fig. 4). A sample of organic material recovered in the PEN-1a unit, dated by the ${ }^{14} \mathrm{C}$ conventional method (Table 2 ), could be correlated with a time of repopulation and agricultural reuse of this region during the medieval period. The lithic remains recovered in the PEN-2 could be attributed to a Neolithic or Chalcolithic occupation of the floodplain.

\subsection{Colmeal}

The site is located $1 \mathrm{~km}$ downstream from the Penascosa trench on the same bank of the river (Fig. 1B and C). Two test holes completed in 1997 in the upstream limit of a large meander reveal a sedimentary sequence composed of alluvial (COL-1a to $1 \mathrm{c}$ units) and slope deposits (COL-2 unit; Fig. 4). The layer of organic material intercalated in the alluvial unit could be correlated to the PEN-1a unit of the Penascosa site. The bottom of the COL-2 unit, at the interface with the schist outcrop, has yielded few non-diagnostic lithic remains (Aubry et al., 2002; Aubry, 2009).

\subsection{Olga da Quinta de Ervamoira}

The site is located a few hundred metres downstream of the Colmeal test holes, in the floodplain of the opposite margin. The four machine-dug trial realized in 2009 , forming an axis orientated perpendicularly to the CôaRiver, have revealed a maximum of eleven GFU of alluvial and colluvial deposits (S2 site). Fragments of ceramics were recovered in the alluvial OE S2-7 unit (Fig. 4), associated with some heated fire pit stone fragments. Their probable secondary position, the absence of decoration and the material used for the fabric do not permit the ascription of a precise chronology between the Neolithic and the Bronze age to these alluvial units. Technologically, non-diagnostic lithic remains were recovered in the OE S1-5 and 6 units (Fig. 4).

\subsection{Rocha 14 Piscos}

The engraved Rock 14 Piscos site is located $3 \mathrm{~m}$ above the riverbed, at a place influenced by the Pocinho dam at the mouth of the Piscos Rivulet, a left-bank tributary of the CôaRiver (Fig. 1B and C). The rock art panel is located in a small topographic terrace at the bottom of an uneven schistose slope. Archaeological work was completed in 2000 and 2003 (Aubry, 2009) to establish the sedimentary sequence at the boundary of this panel preserving Palaeolithic engravings stylistically attributed to the Magdalenian (Baptista, 2008). The sequence is composed of a recent alluvial deposit (R14-1 unit), related to recent flows resulting from the Côa dam project, and four slope deposits (R14-2-5 units; Fig. 4). Nondiagnostic lithic remains (core and flakes of quartz and quartzite) were discovered in the R14-3 and 4 units. The R14-1-4 units are covering the engravings that are stylistically attributed to the Upper Magdalenian (Baptista, 2008).

\subsection{Fariseu}

The site, localised on the central portion of the left bank of a meander of the CôaRiver (Fig. 1B and C), was archaeologically tested in 1999 (Aubry and Baptista, 2000) and excavated in 2005 and 2007 (Aubry et al., 2002; Aubry, 2009). The 3 to 6 m-thick logs observed were divided into ten GFU in the G-92/93 profile (FA-1a to 10) and eight GFU in the Rock 1 profile (FA-1 to 8; Fig. 4). The sediments were accumulated in an alluvial setting and through gravity-driven slope processes (Sellami, 2009a). The sequence conserved Upper Palaeolithic lithic and faunal remains typologically attributed to and dated by ${ }^{14} \mathrm{C}$ AMS and luminescence methods (Table 2) as Final Magdalenian (FA-4 unit), Upper Magdalenian (FA-6 unit), Solutrean (FA-9 unit) and, probably, Gravettian (FA-10 unit).

\subsection{Quinta do Vale do Meão}

This mechanically trial trench was dug perpendicular to the Vilariça fault zone in 2007 on the left bank of the Douro River, $10 \mathrm{~km}$ downstream of the Côa mouth (Fig. 1B), to date and assess fault displacements (Rockwell et al., 2009). The sequence $10 \mathrm{~m}$ above the riverbed is composed of slope (QV-1a to 3b; QVM-1a and 5) and alluvial (QVM-6a to 6e) GFUs (Fig. 4). This section did not revealed archaeological remains, but it provided a complementary chronological framework for several phases of Lateglacial and Holocene alluvial and slope sedimentation in the Douro floodplain.

\section{Stratigraphical, archaeological and palaeoenvironmental correlation}

The geological, archaeological and chronometric data obtained for the studied deposits permit the elaboration of a chrono-stratigraphic framework and the correlation of sedimentary unconformities corresponding to erosive or non-deposition phases (Fig. 4). The sequences preserved at the bottom of the Côa River (Fariseu, Colmeal, Olgas da Quinta de Ervamoira) and Douro valleys (Quinta do Vale do Meão) reveal the existence of a main unconformity between the Pleistocene and Holocene record, in accord with the model of two main alluvial units found in Mediterranean valleys and described by Vita-Finzi (1969): the 'Younger Fill' of historical age, which cut into the 'Older Fill', regarded as being of Late Pleistocene age.

This correlation framework also reveals a lack of sedimentary record in the floodplain for the early Holocene. The ${ }^{14} \mathrm{C}$ ages obtained from organic materials (badly preserved small charcoal fragments) recovered in the most recent alluvial unit at Penascosa in the Côa Valley (PEN-1a: 829-967 cal yr BP) and at Quinta do Vale do Meão in the Douro Valley (QV-2b: 4583-4781 cal yr BP and in QV-3a: 4657-4820 cal yr BP; Table 2 and Fig. 4), as well as the prehistoric and historical ceramics recovered along all the thickness of the slope deposit of FA-2 unit at Fariseu site, indicate that deforestation and agriculture had a direct impact on the destabilisation of the soils, normally stabilised by the vegetation on the slopes, and on the increase in the alluvial clastic input. Such a phenomenon could correspond to a repopulation of the area by farmers at the beginning of the Neolithic and during several historical periods. However, the complex interactive response of the drainage basin to climatic and land use changes remains to be documented in terms of processes and precise chronology.

The data obtained from the study of the Prazo site, located on a granitic plateau ca. $15 \mathrm{~km}$ to the east of the CôaRiver mouth, can compensate partially the Holocene record missing in the floodplain. This site yields a composite sequence that permits the reconstruction of environmental change of the early and middle Holocene, based on the macroscopic study of surface runoff deposits over a granitic bedrock (Fig. 5; Monteiro-Rodrigues and Angelucci, 2004). 
We compare the Côa River Valley data with the Greenland ice core climate proxy record (GRIP; Johnsen et al., 2001) plotted on the SFCP2004 time scale of Shackleton et al. (2004) where Heinrich events (HE) 1-3, the Younger Dryas (YD) and Greenland interstadials (also called Dansgaard-Oeschger, D/O) 1-7 are highlighted (Fig. 5). This proposal also integrates the model proposed by Zilhão and Almeida (2002), based on the study of the sequence of the Lagar Velho rock-shelter site (Leiria, Central Portugal; Angelucci, 2002) and other Gravettian occupations from Central Portugal (see Zilhão, 2003).

For the Pleistocene record, we can thus define two main phases of weathering (W1 and W2 in this paper) of the schist outcrops in the CôaRiver Valley. These phases of weathering are characterised by an increase of the mechanical degradation and sedimentary accumulation of rock fragments produced on the topographic break located at the limit of the floodplain (Figs. 5 and 6). These deposits, revealing a planar macro-structure interpreted as the result of mechanical degradation by temperature cycles (Sellami, 2009a,b), were detected and dated at the Fariseu site (FA-4 and FA-7/8; Fig. 4) and on the slope at Quinta da Barca Sul (QBS-3b), and also in the valley of Douro at Quinta do Vale do Meão (QVM-4a and 5). The chronometric ages obtained by luminescence and ${ }^{14} \mathrm{C}$ methods and the sedimentary processes implicated show a good correlation between these slope deposits, constituted essentially of schist rock fragments, with the chronology of the cold HE1 (Lebreiro et al., 1996) for the W1 phase defined in this paper, and the Younger Dryas (Dansgaard et al., 1989) corresponding to the W2 phase (Figs. 5 and 6).

The alluvial deposits at the base of the Quinta do Vale do Meão sequence and between the two levels considered as reflecting cold events and rock slope weathering (probably W1 and W2) at Fariseu (FA-5 and 6; Figs. 5 and 6) indicate a low energy depositional environment (Sellami, 2009a). The FA-5 and FA-6 units at the Fariseu site correspond to sand members deposited at the limit of the floodplain and affected by several pedological processes resulting from various flood events. By its relative and chronometric age, this paleoenvironmental change (from rock slope to alluvial accumulation) can be related to the Greenland interstadial event 1 , dated by OSL to $15200 \pm 1600 \mathrm{BP}$ (Table 2 and Fig. 5). An earlier alluvial level (FA-3 and FA-3 units) at the Fariseu site, was not dated and is archaeologically sterile. This alluvial deposit overlays the slope deposit corresponding to the Younger Dryas and is truncated by erosion. It corresponds to a low energy deposit, similar to FA-5 and 6 units, at the limit of the floodplain, and could be correlated to the sudden earliest Holocene warming (Dansgaard et al., 1989). This deposit could be contemporary with the large pebbles, gravels and sand deposited on the mid-channel at the Penascosa site, considered early Holocene by Rochette Cordeiro and Rebelo (1996), but has yet to be archaeologically observed at this location.

Another erosive unconformity precedes the slope deposits associated with the cold conditions of the HE1 and affects the top of alluvial units FA-9 and 10, which were only detected in the test pit of the middle part of the Fariseu site (Fig. 4). Charcoal recovered at the top of unit FA-9 yielded a radiocarbon date of $19020 \pm 80{ }^{14} \mathrm{C}$ yr BP (22 581-23 174 cal yr BP; Table 2). The conservation of this unit at the base of the sequence of the central part of the site proves that some alluvial deposits prior to this erosion could be preserved in the Côa floodplain at a depth of less than $5 \mathrm{~m}$ of the present riverbed. However, the immersion of the lower portion of the basin (Fig. 1B) does not provide the data necessary to complete the framework of the environmental changes prior to the Lateglacial.

Data obtained at Cardina I (Bergadà, 2009; Bergadà et al., 2009) and at Olga Grande 4 and 14 (Sellami, 2009b), localised, respectively, at ca. $20 \mathrm{~m}$ above the present riverbed and at ca. $550 \mathrm{~m}$ a.s.l. on the granitic plateau (Fig. 1B), show that the parental materials of the floodplain sequences studied at Fariseu site were mainly provided by the granite of the upper part of the drainage basin (Sellami, 2009b; Fig. 1B).

The micromorphological study of the sequences conserved at Cardina I (Bergadà, 2009; Bergadà et al., 2009) and at Olga Grande 4 and 14 (Sellami, 2009b) allows the reconstruction of the palaeoenvironmental conditions and the processes of formation and preservation of slope deposits on schist and granite rocks, in part deposited before the HE1. Among the features observed at Cardina I in the deposit contemporaneous with the recent Gravettian occupation (dated by TL between $26500 \pm 1800 \mathrm{BP}$ and $30100 \pm 1500 \mathrm{BP}$ ) are platy type sedimentary micro-structure documenting freeze-thaw processes, also apparent, but at a lesser level, in the deposits containing Upper Magdalenian remains (Bergadá, 2009; Bergadá et al., 2009). This structure, characterised by horizontal planar type voids, is produced when the lowering of the ice front is fast and its intensity is not important (Van VlietLanoë, 1987). Its palaeoclimatic significance is that the soil freezes seasonally or that during the cold season freezing is frequent (Sjoerd, 1993). At Cardina I a main hiatus and a stabilisation of the slope are apparent between these two cultural phases in a range that can be evaluated between ca. $27000 \mathrm{BP}$ and $13500 \mathrm{BP}$.

At Olga Grande 4 and 14 sites, a seasonal accumulation of snow cover and slight frost is evidenced by the micro-structure in the sample studied of the deposit containing the Gravettian remains (Sellami, 2009b), dated by TL between $27200 \pm 2300$ BP and $31000 \pm 2500$ BP.

\section{Implications of the fluvial sedimentary environment on the conservation of the archaeological context and visibility of the engravings}

The chronological and environmental framework proposed above points to a better preservation of the occupation levels contemporaneous with the higher sedimentation rate, attested in the sequences during the recent Gravettian and at the end of the Magdalenian, and it reveals several sedimentary hiatus and erosive unconformities between these two phases (Fig. 5).

At Cardina I, the micromorphological study shows a sedimentary hiatus between two slope deposits corresponding to cold conditions, with an age range between ca. 25000 and $15000 \mathrm{BP}$ (Fig. 5). This hiatus could explain the age of $23400 \pm 1500 \mathrm{BP}$ and $20700 \pm 1300 \mathrm{BP}$ obtained by TL on a burnt pebble from the top of the Gravettian level (Valladas et al., 2001; Table 2). It could also explain the fact that at the Fariseu site, the limit is progressive between the alluvial FA-9 unit, where a diagnostically Solutrean artefact bearing heat treatment was recovered, and the FA-10 unit that yielded a lithic assemblage similar to regional Gravettian series. This hiatus is also attested on the granitic plateau and is characterised by an erosion event and the remobilisation of the Upper Solutrean shouldered points throughout the thickness of the second GFU from the top at Olga Grande 4 and 14 sites, underlined by the Upper Magdalenian occupation (Aubry, 2009).

The data available for the sedimentary floodplain record and how it has evolved over time does not allow us to establish a direct correlation between the deposits contemporaneous with the Gravettian and Solutrean occupation and the Côa engravings, but it allow a study of the environmental setting after and during the HE1, affecting the engravings of the older phase or coeval of the younger phase. For the older artistic phase, dated prior to ca. $18400 \mathrm{BP}$, at the upstream limit of its geographical distribution (Figs. 1 and 3; Penascosa and Quinta da Barca sites), the proximity of engraved panels to the riverbed has exposed them to the successive erosive and weathering processes (Figs. 3 and 6 ). In this area of the basin, the preservation of pre-Heinrich Event 1 deposits is unlikely. On the 
Age (ka BP)

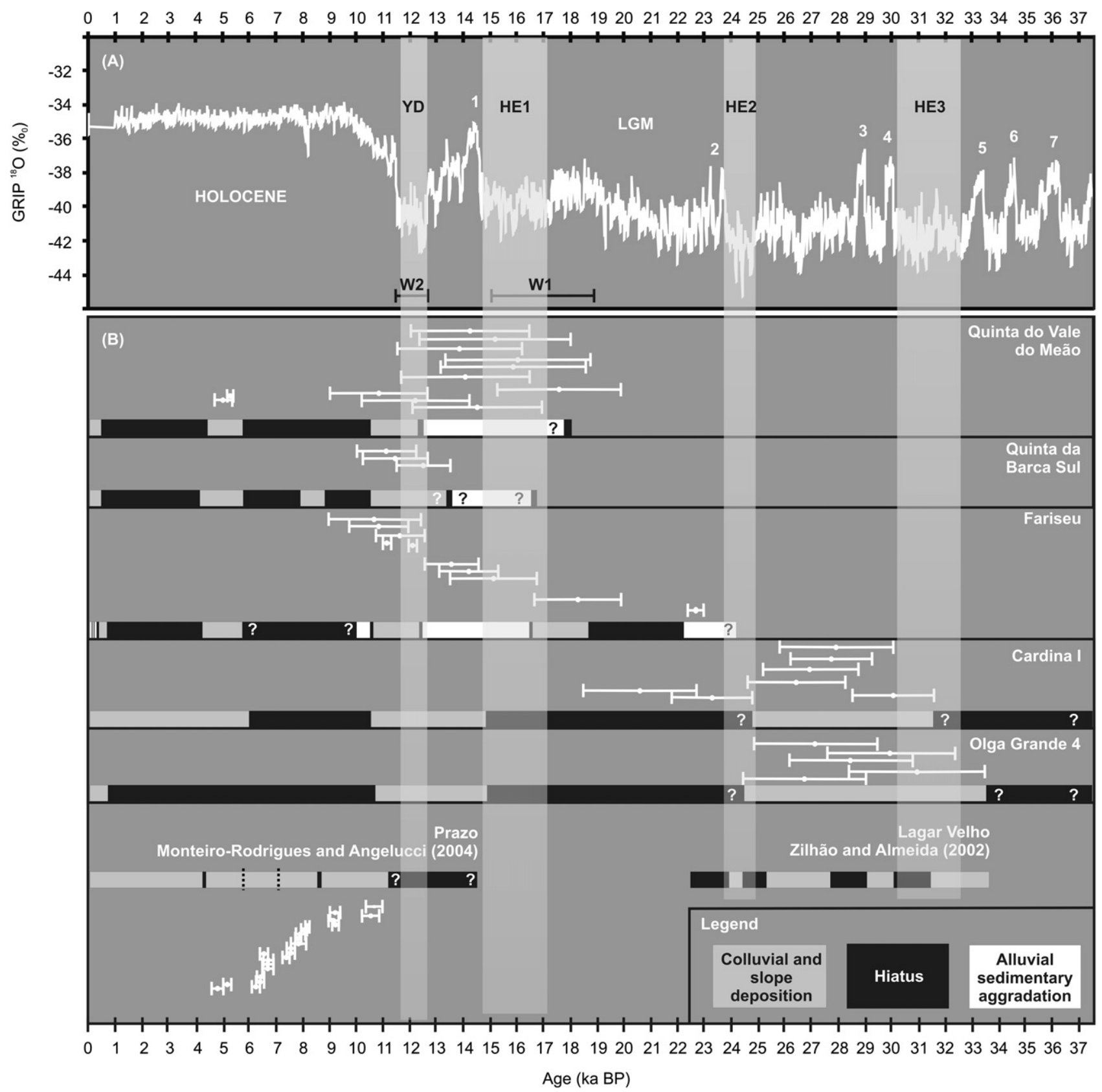

Fig. 5. Proposal of deposition and sedimentary unconformity correlative framework established through data obtained in the Côa River Valley during the last ca. 35 000 yr BP and tentative correlations between the Greenland ice core climate proxy record, Heinrich Events and age of geoarchaeological studied sites samples. Greenland Ice Core Record (GRIP; Johnsen et al., 2001) plotted on the SFCP2004 time scale of Shackleton et al. (2004). Vertical stripes place Heinrich events (HE) 1-3 and the Younger Dryas (YD). Numbers 1-7 refer to the Dansgaard-Oeschger (D/O) or Greenland interstadials, LGM = Last Glacial Maximum, (a). Narrow white bars correspond to age error range $\left({ }^{14} \mathrm{C}\right.$ calibrated age) for samples from the geoarchaeological field units studied (b).

other hand, it is highly probable that most of the engravings at the Penascosa and Quinta da Barca sites were buried by Lateglacial alluvial deposits. For this reason, the topographical and geomorphological conditions of the floodplain are unfavourable to yield any remains of Palaeolithic humans in primary position, only evidenced by engravings in the floodplain margin of this portion of the valley (Zilhão, 1997).

The existence of engraved rocks entirely buried by Holocene deposits younger than the erosion at the base of the section studied at Penascosa and Colmeal sites (Fig. 3) cannot be completely discarded, considering the geophysical profile obtained in front of
Rocks 4 and 5 at Penascosa, which reveals the existence of more than $5 \mathrm{~m}$ of deposits in front of the engravings (Zilhão, 1997). Nevertheless, the spatial distribution and density of the engravings at the base of the slope may be considered an indication of their longitudinal distribution along the river and reveals two clusters at the limits of the Penascosa/Quinta da Barca meander (Baptista et al., 2009; Fig. 1C). However, the localities with engravings stylistically assigned to the older artistic phase and yielding the higher degree of rock weathering, are located on the slope at less than $70 \mathrm{~m}$ of elevation above the current floodplain (Chauvière et al., 2009; Fig. 3). A differential preservation must be taken into account if we 

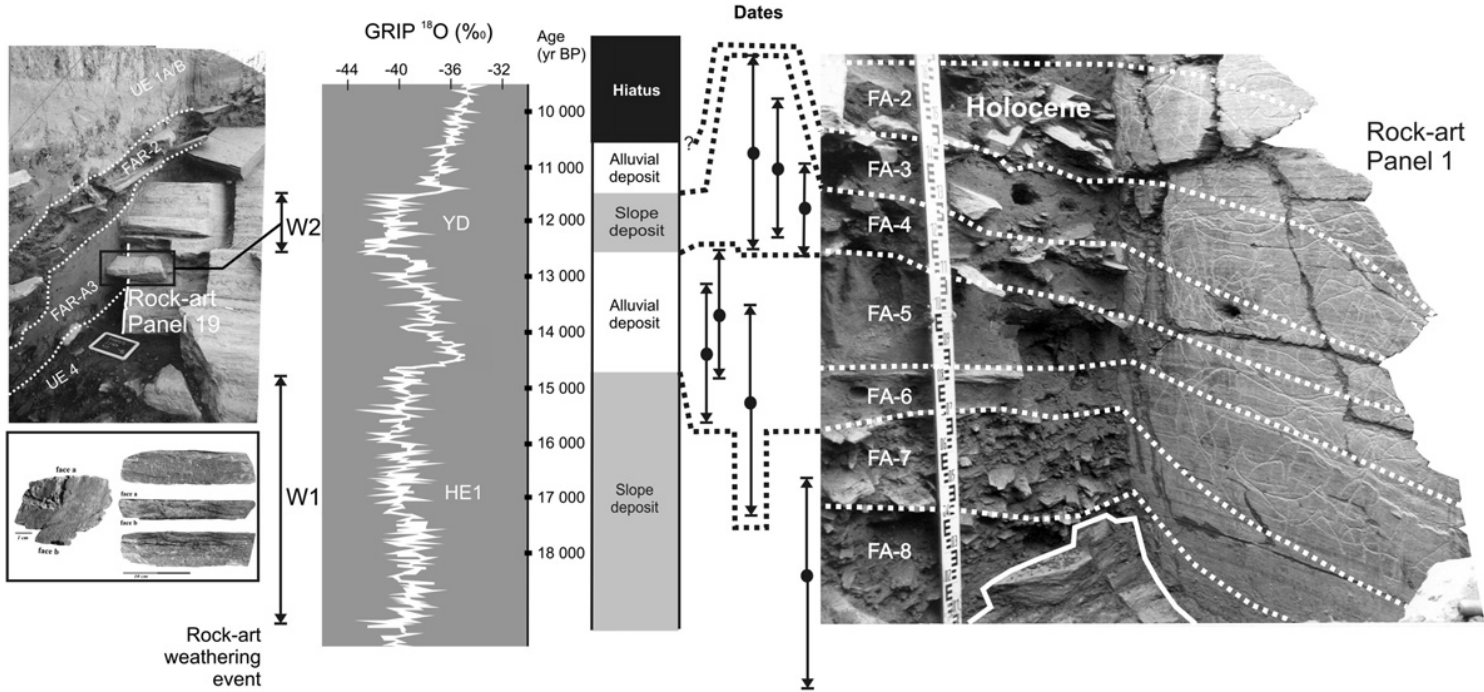

Fig. 6. Fariseu stratigraphic sections observed next to Rock art 1 and 19. Engraved surfaces buried since the deposition of stratigraphic unit FA-3, dated to the early Holocene.

try to interpret the distribution of rock art along the slope, notably in terms of human choices (Baptista et al., 2009).

Downstream from the Colmeal meander, engraved panels of the older phase are located in clusters (Figs. 1C and 3), on panels on an uneven slope topography, or on the concave (inner) margin of meanders. In this setting, the engraved rock panels and deposits are less affected by erosive processes, and a large portion of these are probably buried by Lateglacial and Holocene deposits, as the Fariseu Rocks 1 and 19 sedimentary context documents (Fig. 6). In a geomorphological situation also favourable to the preservation of deposits and archaeological remains (as evidenced by the Lateglacial sedimentary record of Fariseu site), weathering processes probably occurred during and after the Gravettian. However, floodplain deposits related to these events were affected by erosion before the HE1 and only partially preserved at Fariseu site, (Figs. 4 and 7).

The Fariseu site data show that at this elevation in the valley and down to the junction with the Douro River, the Holocene erosion uncovered probably only a small part of engravings of the older artistic phase in the CôaRiver Valley, at the base of the slopes, or in the lowest part of its tributaries. Of a total of 397 representations assigned to the older graphic phase (Baptista et al., 2008, 2009), 90 belong to the same panel (i.e., Rock 1) at Fariseu. Like in Rock 19 from the same site, that yielded only a small part of pecked or deeply incised representations before its complete excavation (Fig. 6), we suggest that more than a quarter of the representations of this phase were not detected during the survey and that the 114 visible figures of this phase from the site of Canada do Inferno (Baptista et al., 2008, 2009) constitute only a small number compared to what must still be buried. The attempt to reconstruct the topography of the Fariseu schist outcrops before the HE1 allows us to predict where engravings could be buried (Fig. 7).

The correlation between the alluvial units of the Fariseu and Quinta do Vale do Meão site sequences reveals a similar sedimentary response to high water flows during the Lateglacial (dated ca. 14 000-15 000 BP; Fig. 5), resulting from a global environmental warming (Steffensen et al., 2008) with higher seasonal discharges or a distinct climatic controlled hydrologic regime (Aubry et al., 2002). Thus, if engravings were also completed along the Douro drainage basin and are preserved at the limit of the floodplain like in the CôaRiver Valley, the Vale do Meão sedimentary record indicates those panels are probably entirely buried by Pleistocene and/or Holocene deposits. Unfortunately, the existence of several dams does not allow confirmation of this assumption.

\section{Conclusions and discussion}

Data on Palaeolithic rock art discovered during the survey carried out since 1995 in the CôaRiver Valley show a regular increase in the detection of panels-currently 330, corresponding to 29 clusters (Baptista and Reis, 2009). However, most of the newly discovered open-air rock art could be dated to the Younger Dryas, on the basis of the stylistic conventions of portable art representations recovered in the FA-4 unit of the Fariseu site (Fig. 2). The detection of new engravings of the older artistic phase is limited by the impossibility of checking the margins of the Côa River Valley in the area flooded by the Pocinho dam located in the Douro drainage basin (Fig. 1B) and the floodplain of this river was immersed by many other dams. Such a situation around the Mazouco engravings, located in a portion of the Douro River Valley affected by another dam in Spanish territory, is the principal limitation to the knowledge of the distribution of engravings of the older graphic phase. Considering that Rock 1 at Fariseu yields 92 representations (Fig. 2D), of a total of 397 figures assigned to the older graphic phase (Baptista et al., 2008, 2009), the equivalent of some of the richest Palaeolithic art caves, we argue that the majority of the rock art of this phase is buried by later deposits at the bottom of the valley (Figs. 6 and 7) and that the open-air rock art currently visible must be a small percentage compared to the buried ones.

The data available in Baptista (2009) suggest that the density of rock art of the older phase in the Côa does not have any equivalent in other tributaries of the Douro drainage basin (Ribeira de Aguiar, Sabor and AguedaRivers). However, we believe that such scenario results from the lack of a systematic survey similar to the work developed before 1995 in the CôaRiver Valley. In fact, the last portion of the river catchment and lower slope of other tributaries of the Douro River Valley probably have a metamorphic bedrock and tectonic faults, a pluvio-nival feed and preservation conditions similar to those we reconstituted for the Côa River Valley during the LGM (Aubry et al., 2002), and geomorphological settings similar to that of the Fariseu site. So far, only the site of Siega Verde, in the Côa River catchment (Fig. 1A), with scarce figures of the older art phasesome of which are partially buried by alluvial deposits dating to the recent Holocene (Alcolea González and Balbín Berhmann, 2006)could constitute an equivalent of those represented at Penascosa and Quinta da Barca sites, and yield clues of the existence of older representations, currently buried but located downstream in the hydrographic basin. Nevertheless, a recent survey of rock art 


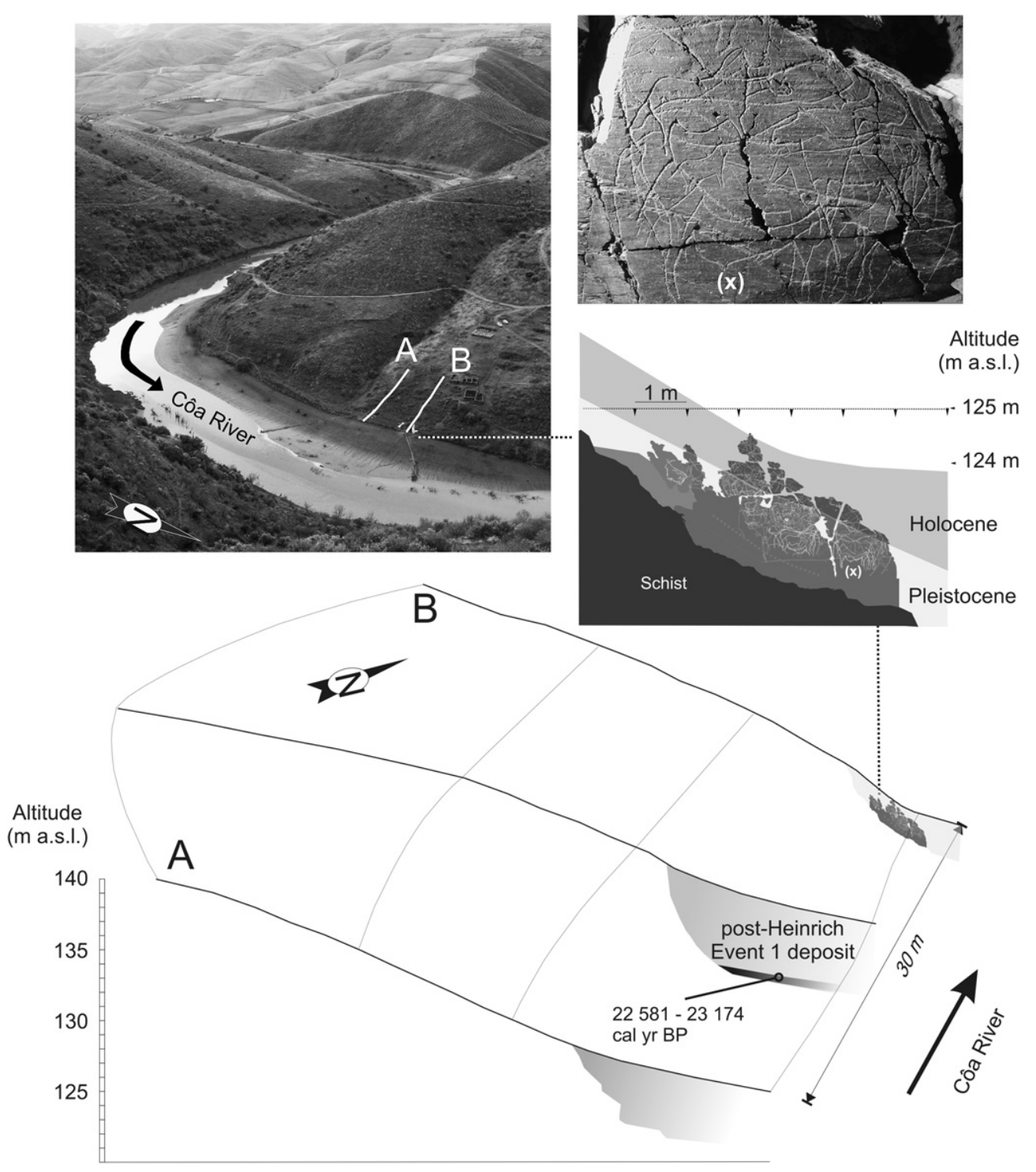

Fig. 7. Fariseu 3D slope profile reconstitution of the sedimentary filling prior to the Heinrich event 1, based on the section observed during the 1999 , 2005 and 2007 excavations, showing the potential area of preservation of buried rock art $(x)$ and the topography of the site during the older artistic phase.

conducted by M. Reis (personal communication) in the lower valley of the Ribeira de Aguiar, a tributary with the confluence immediately downstream of the Côa River on the same left margin of the Douro River, did not reveal any engravings that could be attributed to the older graphic phase represented by Rock 1 of the Fariseu site.

The setting of the most recent phase of Palaeolithic rock art is quite different. Engravings discovered within the last ten years could essentially be dated, by stylistic comparison with portable art, to the end of the Lateglacial or the very beginning of the Early Holocene. These engravings were detected along the slopes of the Côa and Douro River Valleys (Figs. 1C and 3), and up to the top of the schist plateau (altitude over $500 \mathrm{~m}$ ). Accordingly, the panels are apparently not affected by the Younger Dryas phase of weathering evidenced at Fariseu site. The survey realized until 2000 clearly increased the number of rock art figures assigned to this chronological phase, and not only at the bottom of the valley slopes. The distribution of the new finds on the Côa and Douro River Valleys and recent discoveries in other drainage basins of southern Iberia (Collado, 2009) reveal the large potential and the predictable increase of rock art assigned to the Late Palaeolithic or initial Holocene artistic phase.
The most favourable geomorphological setting for the preservation of pecked and deeply superposed engravings of the most famous artistic phase of the CôaRiver Valley is the interface between the rocky slope and the floodplain. Data revealed successive burial/uncovering phases of the engraved panels preserved on the CôaRiver margin during the Pleistocene, which are related to a re-organisation of the drainage basin imposed by the hydrological system (Aubry et al., 2002). The sedimentary cover of the engravings, combined with the characteristic siliceousmetallic films developed in the diaclases of metamorphic rocks (Chauvière et al., 2009; Fernandes, 2009; Pope, 2000), were probably the most important factors in their preservation during the several phases of weathering related to the cold events of the LGM and Lateglacial.

Data accumulated over the last 15 years in Iberia suggest that the CôaRiver Valley was an unusual ecological mosaic of complementary environments between the bottom valley and the Meseta plateau during the LGM. The large variety of biotic resources in a small territory resulted in a permanent exploration by hunter-gatherers throughout the Upper Palaeolithic (Aubry, 2009; Aubry et al., 2002). Specific geological and climatic conditions (Chauvière et al., 2009; 
Fernandes, 2009) allowed the partial preservation of a monumental rock art made by Solutrean or (more probably) Gravettian human groups (Aubry, 2009; Aubry and Sampaio, 2008). The sedimentary record was a factor in its preservation, but it also constitutes a limitation in the detection of most of them that are still covered by sediment on the downstream $7 \mathrm{~km}$ of the CôaRiver Valley.

Better understanding of the environmental changes over time, and excavations based on a predictive model of the geomorphological areas favourable for both the preservation of rock art panels and prehistoric human occupation, could radically change the corpus of data and our conception of the first artistic manifestations in Europe.

\section{Acknowledgements}

Fieldwork and analyses were supported by the Instituto Português de Arqueologia and the Instituto de Gestão do Património Arquitectónico e Arqueológico of the Portuguese Ministry of Culture (IGESPAR-IP), text revision by the Centro de Estudos de Geografia e Ordenamento do Território (CEGOT). We thank our colleagues Christophe Delage and J. Dinis (Departamento de Ciências da Terra, Faculdade de Ciências e Tecnologia, Universidade de Coimbra) and the two anonymous reviewers of JAS for their stimulating reviews and constructive improvement of the manuscript.

\section{References}

Alcolea González, J.J., Balbín Behrmann, R., 2006. Arte paleolítico al aire libre. El yacimiento rupestre de Siega Verde, Salamanca. Memorias 16. In: León, Arqueología en Castilla y (Ed.), Junta de Castilla y León, p. 422.

Angelucci, D.E., 2002. The geoarchaeological context. In: Zilhão, J., Trinkaus, E. (Eds.) Portrait of the Artist as a Child. Portrait of the artist as a Child. The Gravettian Human Skeleton from the Abrigo do Lagar Velho and its Archaeological Context. Instituto Português de Arqueologia, Trabalhos de Arqueologia, vol. 22, pp. 58-91.

Aubry, T., 2009. 200 séculos da história do Vale do Côa: incursões na vida quotidian a do caçadores-artistas do Paleolítico. In: Trabalhos de Arqueologia, vol. 52. IGESPAR-IP, Lisboa.

Aubry, T., Baptista, A.M., 2000. Une datation objective de l'art du Côa. La Recherche, Hors Série 4 (11), 54-55.

Aubry, T., Garcia Diez, M., 2001. Actualité sur la chronologie et l'interprétation de l'art de la vallée du Côa (Portugal). Les Nouvelles de l'Archéologie 82, 52-57.

Aubry, T., Mangado Llach, X., Sellami, F., Sampaio, J.D., 2002. Open-air rock-art. Territories and modes of exploitation during the upper paleolithic in the Côa valley (Portugal). Antiquity 76 (291), 62-76.

Aubry, T., Sampaio, J.D., 2008. Fariseu: new chronological evidence for open-air Palaeolithic art in the Côa valley (Portugal). Project Gallery. Antiquity 82 (316)

Bahn, P., 1985. Ice Age drawing on open rock faces in the Pyrenees. Nature 313 $530-531$.

Bahn, P. 1995. Cave art without the caves. Antiquity 69, 231-237.

Balbín Behrmann, R., Alcolea González, J.J., Santoja, M., Perez, R., 1991. Siega Verde (Salamanca). Yacimiento artístico paleolítico al aire libre. Del Paleolítico a la Historia. Museu de Salamanca, Salamanca, pp. 33-48.

Baptista, A.M., 1999. No Tempo sem Tempo. A arte dos caçadores paleolíticos do Vale do Côa. Vila Nova Foz Côa. Ed. Parque Arqueológico do Vale do Côa.

Baptista, A.M., 2001. Ocreza (Evendos, Mação, Portugal Central). Um novo sítio com arte paleolítica de ar livre". In: Cruz, A.R. e Oosterbeek, L., Territórios, mobilidade e povoamento no alto Ribatejo II - Santa Cita e o Quaternário da região, Tomar, CEIPHAR (Arkeos, 11), pp. 163-192.

Baptista, A.M., 2004. Arte paleolítica de ar livre no rio Zêzere (Barroca, Fundão), Ebvrobriga, 1, Fundão, Museu municipal José Monteiro, pp. 9-16.

Baptista, A.M., 2008. Aspecto da Arte Magdalenense e Tardiglaciar no Vale do Côa. Actas do Fórum Valorização e Promoção do Património Regional, Coord. André Tomas Santos, Luís Luís, vol. 3. Do Paleolítico à Contemporaneidade, pp 16-31.

Baptista, A.M., 2009. Aspectos da Arte Magdalenense e Tardiglaciar no vale do Côa. In: Actas da sessão "Do Paleolítico à Contemporaneidade - estudos sobre a História da Ocupação Humana em Traz-os-Montes, Alto Douro e Beira Interior". Fórum Valorização e Promoção do Património Regional. pp. 14-31.

Baptista, A.M., Varela Gomes, M., 1995. Arte rupestre do Vale do Côa 1. Canada do Inferno. Primeiras impressões. Trabalhos de Antropologia e Etnologia 35 (4), 349-422.

Baptista, A.M., Santos, A.T., Correia, D., 2008. Estruturação simbólica da arte Gravetto-Solutrense em torno do monte do Fariseu (Vale do Côa). In. III Congresso de arqueologia, Trás-os-Montes, alto Douro e beira interior, Actas da sessão, Pré-história, gestos intemporais, André Tomas Santos, Jorge Davide Sampaio e João Muralha (coord.), pp. 38-61.
Baptista, A.M., Santos, A.T., Correia, D., 2009. O santuário arcaico do Vale do Côa: novas pistas para a compreensão da estruturação do Bestário Gravetense e/ou Gravetto-solutrense. Arte Prehistórico al Aire libre en el Sur de Europa, Rodrigo de Balbín Berhmann (ed.), Documentos PAHIS, pp. 89-144.

Baptista, A.M., Reis, M., 2009. Prospecção da Arte Rupestre na Vale do Côa e Alto Douro português. Arte Prehistórico al Aire libre en el Sur de Europa, Rodrigo de Balbín Berhmann (ed.), Documentos PAHIS, pp. 145-192.

Baptista, A.M., Santos, A.T., 2010. Confronting two sceneries on the same stage from Gravettian-Solutrean to Magdalenian in Penascosa/Quinta da Barca, Portugal In: Bettencourt, Ana M.S., Jesus Sanches, M., Alves, Lara B., Valarce, Ramon Fábregas (Eds.), Proceedings of the XV World Congress of the International Union for Prehistoric and Protohistoric Sciences. Conceptualising Space and Place. On the Role of Agency, Memory and Identity in the Construction of Space from the Upper Palaeolithic to the Iron Age in Europe C41 and C72. BAR International Series 2058, pp. 61-69.

Bergadà, M.M., 2009. Análisis micromorfológico de la secuencia sedimentaria de Cardina I (Salto do Boi, Vila Nova de Foz Côa, Portugal). In: Aubry, Thierry (Ed.), 200 séculos da história do Vale do Côa: incursões na vida quotidiana do caçadoresartistas do Paleolítico. Trabalhos de Arqueologia 52, pp. 112-127. Capítulo 4.4.

Bergadà, M.M., Mangado, X., Aubry, T., Fullola, J.M., 2009. Geoarqueología, micromorfología y paleoambiente del Pleistoceno superior de Cardina I (Salto do Boi, Vila Nova de Foz Côa, Portugal). VII Reuniao del Cuaternario Ibérico. Faro, 2009, pp. 236-239.

Brown, A.G., 1997. Alluvial Geoarchaeology: Floodplain Archaeology and Environmental Change. Cambridge Manuals in Archaeology. Cambridge University Press.

Chauvière, F.X., Tymula, S., Calame, A., Dechanez, I., 2009. Capítulo 7.3. Conservation et évolution des surfaces rocheuses gravées et piquetées de la Vallée du Côa: les données du projet "Quinta da Barca Sul”. In: Aubry, Thierry (Ed.), 200 séculos da história do Vale do Côa: incursões na vida quotidiana do caçadores-artistas do Paleolítico. Trabalhos de Arqueologia 52, pp. 443-477.

Collado, H., 2009. Arte rupestre prehistórico en Extremadura 1997-2006. In: Behrmann, Rodrigo de Balbín (Ed.), Arte Prehistórico al aire libre en el Sur de Europa. PAHIS, Junta de Castilla e León, pp. 287-322.

Dansgaard, W., White, J.W.C., Johnson, S.J., 1989. The abrupt termination of the Younger Dryas event. Nature 339, 532-533.

Dorn, R.I., 1997. Constraining the age of the Côa valley (Portugal) engraving with radiocarbon dating. Antiquity $71,105-115$

FAO-Isric, 1990. Guidelines for Soil Description, third ed.s. FAO, Roma.

Fernandes, A.P.B., 2009. Conservation of the CôaValley rock art outcrops: a question of urgency and priorities. Project Gallery. Antiquity 319.

Johnsen, S.J., Dahl-Jensen, D., Gundestrup, N., Steffensen, J.P., Clausen, H.B. Miller, H., Masson-Delmotte, V., Sveinjörnsdottir, A.E., Whitte, J., 2001. Oxygen isotope and paleotemperature records from six Greenland ice-core stations: Camp-Century, dye-3, GRIP, GIPS2, Renland and NorthGRIP. Journal of Quaternary Science 16 (4), 299-307.

Jorge, S.O., Jorge, V.O., Almeida, C.A.F., de Sanches, M.J., Soeiro, M.T., 1981. Gravura rupestres de Mazouco (Freixo de Espada-à-Cinta). Arqueologia 3. Porto, 3-12.

Keeley, H.C.M., Machail, R.I., 1981. A Soil Handbook for Archaeologists, vol. 18 Institute of Archaeology Bulletin, London, pp. 225-243.

Lebreiro, S.M., Moreno, J.C., MacCave, I.N., Weaver, P.P.E., 1996. Evidence of Heinrich event layers of Portugal (Tore Seamourth, $39^{\circ} \mathrm{N}, 12^{\circ} \mathrm{W}$ ). Marine Geology 131, 47-56.

Mercier, N., Valladas, H., Froget, L., Jorons, J.-L., Reyss, J.-L., Aubry, T. 2001. Application de la méthode de la thermoluminescence à la datation des occupations paléolithiques de la vallée du Côa. Actes du Colloque : "Les premiers hommes modernes de la Péninsule ibérique”, Vila Nova de Foz Côa, 22-24/10/1998, 275-280.

Mercier, N., Valladas, H., Aubry, T., Zilhão, J., Jorons, J.L., Reyss, J.L., Sellami, F., 2006 Fariseu: first confirmed open-air paleolithic parietal art site in the Côa Valley (Portugal). Antiquity 80 (310).

Monteiro-Rodrigues, S., Angelucci, D., 2004. New data on the stratigraphy and chronology of the prehistoric site of Prazo. Revista Portuguesa de Arqueologia 7 (1), 39-59.

Pope, G.A., 2000. Weathering of Petroglyphs: direct assessment and implications for dating methods. Antiquity 74, 33-43.

Rippol, S., Municio, L., 1992. Las representaciones de estilo paleolítico en el conjunto de Domingo Garcia (Segóvia). Espacio. Tiempo y Forma (UNED), Série I, Prehistória y Arqueologia 5, 107-138.

Rochette Cordeiro, A.M. Rebelo, F., 1996. Carta geomorfológica do Vale do Côa a jusante de Cidadelhe. Cadernos de Geografia 15, 11-33.

Rockwell, T., Fonseca, J., Madden, C., Dawson, T., Owen, L.A., Vilanova, S., Figueiredo, P., 2009. Palaeoseismology of the Vilarica Segment of the Manteigas-Braganca fault in northeastern Portugal. Geological Society, London, Special Publications 316 (1), 237-258.

Sacchi, D., 2002. Propos liminaires. In: Actes du Colloque "L'art Paléolithique à l'air libre: le Paysage modifié par l'image”, 07-09/10/1999. (Coor.) D. Sacchi, pp. 7-11.

Sacchi, D., Abelanet, J., Brulé, J.L., Massiac, Y., Rubiella, C., Vilette, P., 1988. Les gravures rupestres de Fornols-Haut, Pyrénées-Orientales. L'Anthropologie 92 (1), 87-100.

Sellami, F., 2009a. Capítulo 4.2. Les données de la séquence stratigraphique du site de Fariseu: processus de déposition et d'érosion des dépôts en limite de la plaine alluviale du Côa. In: Aubry, Thierry (Ed.), 200 séculos da história do Vale do Côa: incursões na vida quotidiana do caçadores-artistas do Paleolítico. Trabalhos de Arqueologia 52, pp. 103-108.

Sellami, F., 2009b. Capítulo 4.3. Les processus de formation, conservation et évolution des dépôts quaternaires sur les granites de Mêda-Escalhão: Olga 
Grande 4 et 14 de Pedras Altas. In: Aubry, Thierry (Ed.), 200 séculos da história do Vale do Côa: incursões na vida quotidiana do caçadores-artistas do Paleolítico. Trabalhos de Arqueologia 52, pp. 109-112.

Shackleton, N.J., Fairbanks, R.G., Chiu, T.-C., Parrenin, F., 2004. Absolute calibration of the Greenland time scale: implications for Antarctic time scale and for $\Delta^{14} \mathrm{C}$. Quaternary Science Reviews 23, 1513-1522.

Sjoerd, A., 1993. Cryogenic Microfabrics and Macrostructures: Interrelations, Processes and Palaeoenvironmental Significance. Thesis Vrije Universiteit Amsterdam, The Netherlands.

Steffensen, P.D., Andersen, K.K., Bigler, M., Clausen, H.B., Dahl-Jensen, D., Fischer, H., Goto-Azuma, K., Hansson, M., Johnsen, S.J., Jouzel, J., Masson-Delmotte, V., Popp, T., Rasmussen, S.O., Röthlisberger, R., Ruth, U., Stauffer, B., SiggaardAndersen, M.L., Sveinbjörnsdóttir, A.E., Svensson, A., James, W., White, C., 2008. High-Resolution Greenland ice core data show abrupt climate change Happens in few years. Science 321 (5889), 680-684.

Valladas, H., Mercier, N., Froget, L., Jorons, J.L., Reyss, J.L., Aubry, T., 2001. TL dating of upper paleolithic sites in the Côa valley (Portugal). Quaternary Science Reviews 20 (5-9), 939-943.

Van Vliet-Lanoë, B., 1987. Dynamique périglaciaire actuelle et passée apport de l'étude micromorphologique et de l'experimentation. Bulletin de l'Association Française pour l'étude du Quaternaire-3, 113-132.

Vita-Finzi, C., 1969. The MediterraneanValleys: Geological Changes in Historical Times. CambridgeUniversity press, Cambridge.
Watchman, A., 1995. Recent petroglyphs, Foz Côa. Rock Art Research 12 (2), 104-108.

Watchman, A., 1996. A review of the theory and assumption in the AMS dating of the Foz Côa petroglyphs, Portugal. Rock Art Research 13 (1), 21-30.

Weninger, B., Jöris, O., 2004. Glacial radiocarbon calibration: the CalPal program. In: Higham, T., Bronk Ramsey, C., Owen, C. (Eds.), Radiocarbon and Archaeology. Fourth International Symposium, Oxford.

Zilhão, J., 1995. The age of the Côa valley (Portugal) rock-art: validation of archaeological dating to the Palaeolithic and refutation of "scientific" dating to historic or proto-historic times. Antiquity 69 (266), 883-901.

Zilhão, J., (coord.) 1997. Arte Rupestre e Pré-História do Vale do Côa. Trabalhos de 1995 - 1996. Relatório Científico ao Governo da República portuguesa elaborado nos termos da resolução do Conselho de Ministros $n^{\circ} 4 / 96$, de 17 de Janeiro.

Zilhão, J., 2003. Vers une chronologie plus fine du cycle ancien de l'art paléolithique de la Côa: quelques hypothèses de travail. In: Balbín Behrmann, R, Buena Ramírez P. ed. El arte prehistórico desde los inicios des siglo XX: Primer symposium internacional de arte prehistórico de Ribadesella. Ribadessella: Associación Cultural Amigos de Ribadesella, pp. 75-90.

Zilhão, J., Almeida, F., 2002. Chapter 3, the Archeological framework. In: Zilhão, J., Trinkaus, E. (Eds.), Portrait of the Artist as a Child. The Gravettian Human Skeleton from the Abrigo do Lagar Velho. Lisboa, IPA. Trabalhos de Arqueologia 22, pp. 29-57. 